\title{
Evolution of multivariate drought hazard, vulnerability and risk in India under climate change
}

\author{
Venkataswamy Sahana ${ }^{1}$, Arpita Mondal ${ }^{1,2}$
}

${ }^{1}$ Department of Civil Engineering, Indian Institute of Technology Bombay, Powai, Mumbai 400076, India

$5{ }^{2}$ Interdisciplinary Program in Climate Studies, Indian Institute of Technology Bombay, Powai, Mumbai 400076, India.

Correspondence to: Arpita Mondal (marpita@civil.iitb.ac.in)

\begin{abstract}
Changes in climate and socio-economic conditions pose major threat to water security, particularly in the denselypopulated, agriculture-dependent and rapidly developing country of India. Therefore, for cogent mitigation and adaptation planning, it is important to assess the future evolution of drought hazard, vulnerability and risk. Earlier studies demonstrate projected drought risk over India on the basis of frequency analysis and/or hazard assessment alone. This study investigates and evaluates the change in projected drought risk combining vulnerability and hazard information at a country-wide scale for future climatic and socio-economic conditions. A multivariate standardized drought index (MSDI) accounting for concurrent deficits in precipitation and soil moisture is chosen to quantify droughts. Drought vulnerability assessment is carried out combining exposure, adaptive capacity and sensitivity indicators, using a robust multi-criteria decision-making method called

15 the Technique for Order Preference by Similarity to an Ideal Solution (TOPSIS). In the worst-case scenario, though there is a projected decrease in the area under high or very high drought hazard classes in the country by approximately $7 \%$, presumably due to projected rise in precipitation, a $33 \%$ rise in the areal extent of high or very high drought vulnerability classes is depicted. Regions of West Uttar Pradesh, Haryana, West Rajasthan and Odisha are found to be high risk under all scenarios. Bivariate choropleth analysis shows that the projected drought risk is majorly driven by change in drought vulnerability attributable to societal developments, rather than changes in drought hazard resulting from climatic conditions. The present study can aid policy makers, administrators and drought managers in developing decision support systems for efficient drought management.
\end{abstract}

\section{Introduction}

Droughts play a major role in water resources planning and management, agronomy and freshwater availability (Mishra and Singh, 2010, 2011). Droughts may be exacerbated by climate change or societal developments or by a combination of the two.

25 For building drought resilience, it is important to assess the role of these changes on the evolution of drought at regional scales, particularly for rapidly-growing heavily agriculture-dependent countries such as India. Though socio-economic development is reported to have a greater impact on the water availability as compared to the climate induced impacts in some regions across the globe, the role of climate change cannot be entirely eliminated (Koutroulis et al., 2019a). Representative Concentration 
Pathways (RCPs; van Vuuren et al., 2011) that are radiative forcing scenarios for different greenhouse gas emission levels are commonly used for climate change impact studies. Shared Socio-economic Pathways (SSPs; O'Neill et al., 2017), on the other hand, provide different narratives of future societal development. Plausible combinations of different RCPs and SSPs are useful to study the future projections of drought risk (Kim et al., 2020).

According to the Intergovernmental Panel on Climate Change (IPCC) Fifth Assessment Report (AR5) (IPCC, 2014), risk of an extreme event can be quantified as a product of hazard, vulnerability and exposure. Drought hazard is a function of magnitude and occurrence probability of drought events. On the other hand, drought vulnerability is the degree to which a region is susceptible to drought and is a function of sensitivity, adaptive capacity and exposure components. These components in turn describe the socio-economic, physical and infrastructural factors and are illustrated through drought vulnerability indicators. A comprehensive drought risk assessment involves proper selection of drought indicators for hazard analysis and proper selection of drought vulnerability indicators and reliable aggregation technique for vulnerability analysis (Carrão et al., 2016; Naumann et al., 2014; Sahana et al., 2021). By virtue of taking into consideration both drought hazard and vulnerability, a combination of RCP and SSP scenarios offer a comprehensive approach for drought risk projection.

Several studies have carried out risk assessment of drought and water availability across different regions of the world under changing climate and socio-economic conditions. Singh \& Kumar (2019) quantified the water availability in the Indian region due to climate and demographic changes. Ahmadalipour et al. (2019) carried out drought risk assessment in the African region for different population growth and climate change scenarios. Chen et al. (2021) evaluated the effect of changing climate, population and GDP on the drought risk for China. Park et al. (2020) presented drought risk projections under changing meteorological conditions and socio-economic scenarios for South Korea. A comprehensive drought risk assessment for Europe was carried out by Koutroulis et al. (2018) under changing climate and socio-economic scenarios by evaluating exposure, sensitivity and adaptive capacity components for the projected period. Along similar lines, Koutroulis et al. (2019) quantified the global water availability under high-end climate change. Water use vulnerability was assessed by Kim et al. (2020) for a river basin in Korea for different climate and socio-economic scenarios.

For the Indian region, projections of drought hazard/risk or water availability are developed in earlier studies using climate scenarios alone (Aadhar \& Mishra, 2020, 2021; Gupta et al., 2020; Gupta \& Jain, 2018) with the exception of Singh and Kumar (2019) who consider the role of both climate and socio-economic scenarios for obtaining future projections of water availability

55 (Singh and Kumar, 2019). However, Singh and Kumar (2019) represent future socio-economic changes using a simplistic approach that considers changes in population alone. A combination of RCP and SSP scenarios by integrating hazard and vulnerability information is required to assess drought risk in India in the near and far future. Further, most studies that assess drought hazard under climate change scenarios consider either univariate or multivariate approaches based on precipitation deficits and temperature effects (Aadhar \& Mishra, 2020, 2021; Gupta et al., 2020; Gupta \& Jain, 2018). However, droughts can often manifest as a complex interplay of multiple influencing variables necessitating a multivariate approach for 
characterization of drought hazard (Sahana et al., 2020). For the agrarian country of India, agro-meteorological drought hazard projections should consider deficits in precipitation or soil moisture or both.

The present study aims at comprehensive drought risk projections for India by accomplishing the following objectives: a) Multivariate drought hazard projection using Multivariate Standardized Drought Index (MSDI) that considers concurrent deficits in precipitation and soil moisture for future warming scenarios. b) Drought vulnerability projection considering combinations of RCP and SSP scenarios, using a list of drought vulnerability indicators that represent exposure, sensitivity and adaptive capacity components. c) Drought risk projection integrating hazard and drought vulnerability information. d) Development of bivariate choropleth plots under future scenarios to quantify the individual roles of climate and societal changes in driving drought risk, and d) Identification of regions and zones that are expected to be under worst drought risk conditions in the near and far future.

\section{Materials and methods}

\subsection{Data}

\subsubsection{Hydro-climatic variables}

The multivariate drought risk assessment focusing on agricultural drought, requires a combined analysis of precipitation as

75 well as soil moisture deficiencies. The drought hazard assessment for baseline period (1980-2015) requires observed hydroclimatic variables. Gridded daily precipitation data $(\mathrm{mm})$ at $0.25^{\circ}$ lat. $\times 0.25^{\circ}$ lon. resolution is obtained from India Meteorological Department (IMD) (Pai et al., 2014). This dataset has been employed in various studies over Indian region (Sahana et al., 2021). Gridded monthly root-zone soil moisture data $\left(\mathrm{m}^{3} / \mathrm{m}^{3}\right)$ over the Indian region at $1 / 2^{\circ}$ lat. $\times 2 / 3^{\circ}$ lon . resolution is obtained from Modern-Era Retrospective Analysis for Research and Application (MERRA-Land). This dataset

80 has been employed for drought studies across the world (Farahmand \& AghaKouchak, 2015; AghaKouchak, 2015) and also for Indian regions (Sahana et al. 2020; Sahana et al., 2021). The above two datasets are regridded to a common spatial resolution of $0.5^{\circ}$ lat. $\times 0.5^{\circ}$ lon. and rescaled to monthly frequencies for the historical drought hazard assessment.

In order to evaluate the projected drought hazard over India, the projected precipitation and soil moisture data at a spatial resolution of $0.5^{\circ}$ lat. $\times 0.5^{\circ}$ lon. is obtained from the Inter-Sectoral Impact Model Intercomparison Project (ISIMIP)

85 (Warszawski et al., 2014). The historical (1980-2005) and projected (2006-2099) data from available GCMs namely GFDLESM2M, HADGEM2-ES, IPSL-CM5A-LR and MIROC5, and for two RCPs - RCP2.6 and RCP6.0 are downloaded from ISIMIP data portal (https://esg.pik-potsdam.de/search/isimip/). The daily precipitation data $\left(\mathrm{kg} \mathrm{m}^{-2} \mathrm{~s}^{-1} 1\right)$ is already bias corrected using the EartH2Observe observations, WFDEI and ERA-Interim data Merged and Bias-corrected for ISIMIP (EWEMBI). This data has been previously used to study the soil moisture droughts for Europe (Grillakis, 2019) and terrestrial

90 water storage in mainland China (Jia et al., 2020). The country-wide average annual precipitation for the projected period is higher compared to the baseline periods as shown in Figure S1. As a part of ISIMIP2b experiments, the LPJmL impact model 
(Sitch et al., 2003) is driven by the bias-corrected GCM precipitation to simulate the root-zone soil moisture $\left(\mathrm{kg} \mathrm{m}^{-2}\right)$. For our study, the soil moisture data upto 3 layers accounting for $1 \mathrm{~m}$ depth is used. The spatial pattern of annual mean surface soil moisture for India from the LPJmL impact model is consistent with the satellite-based Essential Climate Variable soil moisture product (Gu et al., 2019). Although the simulated soil moisture data underestimates the monsoon months' soil moisture (June, Jul, Aug, Sep) during the historic period (1980-2005), we did not perform the bias correction, since we intend to capture the variability in the soil moisture rather than their magnitudes for drought index calculation. The country-wide average annual soil moisture for the projected period is slightly lower compared to the baseline periods as shown in Figure S2. The units of projected precipitation and soil moisture datasets are converted to $\mathrm{mm}$ and $\mathrm{m}^{3} / \mathrm{m}^{3}$ respectively and brought to monthly timescales. Although climate variables from CMIP6 are available, drought responses by CMIP5 models are similar to that of CMIP6 (Cook et al., 2020). Hence we proceeded with the CMIP5 data for drought hazard assessment.

\subsubsection{Drought vulnerability indicators}

The country-wide drought vulnerability indicators adopted for drought vulnerability assessment are listed in Table 1, along with their sources, relevance and correlation to drought vulnerability for both the observed (around the year 2010) and projected datasets (2005-2100). Drought vulnerability indicators such as groundwater availability, irrigation index and waterbody fraction for the projected period are not directly available. Hence, these indicators are proxied by representative indicators (Table 1) through multiple linear regression (MLR). Finally, drought vulnerability indicators are extracted for the RCP2.6SSP2 and RCP6.0-SSP2 scenarios for the periods 2060 and 2100 so as to represent different climate and socio-economic scenarios for the near future and far future periods respectively.

\subsection{Methods}

The methodology adopted to study the evolution of drought risk is given in Figure 1. Drought hazard assessment is carried out through the computation of drought hazard index (DHI) based on the deficiencies in precipitation and soil moisture using MSDI. A robust multi-criteria decision making method known as Technique for Order Preference by Similarity to an Ideal Solution (TOPSIS) is used for drought vulnerability assessment, to aggregate drought vulnerability indicators and arrive at the

115 drought vulnerability index (DVI) (detailed steps for DHI and DVI calculation is presented in Section 1 in the supplement). The hazard and vulnerability information computed in the form of DHI and DVI respectively, are combined to evaluate the drought risk. The definition of risk as provided by IPCC (AR5) (IPCC, 2014) is adopted.

Risk $=f($ Hazard, Vulnerability $)=D H I \times D V I$

Drought risk values computed using Eq 1 are further standardized to obtain the Drought Risk Index (DRI).

120 Apart from representing the risk as product of hazard and vulnerability, it can also be represented using bivariate choropleth (Mohanty et al., 2020). Colorscale of these bivariate choropleth is characterized by all possible combinations of DHI and DVI classes. Such maps clearly demarcate the hazard-driven and vulnerability-driven risk. 
Table 1. Drought vulnerability indicators used for drought vulnerability assessment. The sources for indicators in baseline period and projected period along with their relevance and correlation with drought vulnerability is presented. Representative indicators

to arrive at the drought vulnerability indicators for projected period are also listed.

\begin{tabular}{|c|c|c|c|c|c|}
\hline \multirow[b]{2}{*}{ Data } & \multirow[b]{2}{*}{$\begin{array}{l}\text { Relevance to drought } \\
\text { vulnerability }\end{array}$} & \multirow{2}{*}{$\begin{array}{l}\text { Correlation } \\
\text { with drought } \\
\text { vulnerability }\end{array}$} & \multirow{2}{*}{$\begin{array}{c}\text { Observed } \\
\text { Source }\end{array}$} & \multicolumn{2}{|c|}{ Projected } \\
\hline & & & & Source & Representative Indicator \\
\hline $\begin{array}{l}\text { Population } \\
\text { density }\end{array}$ & $\begin{array}{l}\text { Demographic attribute for } \\
\text { assessing social } \\
\text { vulnerability. }\end{array}$ & Positive & $\begin{array}{l}\text { NASA Socioeconomic Data and } \\
\text { Applications Centre (SEDAC) } \\
\text { (http://sedac.ciesin.columbia.edu/data/se } \\
\text { t/gpw-v4-population-density) }\end{array}$ & \multirow{5}{*}{$\begin{array}{l}\text { Inter-Sectoral Impact } \\
\text { Model Intercomparison } \\
\text { Project (ISIMIP2b } \\
\text { experiments) data archive } \\
\text { (Warszawski et al. 2014) }\end{array}$} & Population (SSP2) \\
\hline GDP & $\begin{array}{l}\text { Economic welfare for } \\
\text { assessing economic } \\
\text { vulnerability as well as } \\
\text { adaptive capacity. }\end{array}$ & Negative & (Ghosh et al., 2010) & & GDP (SSP2) \\
\hline $\begin{array}{l}\text { Irrigation } \\
\text { Index }\end{array}$ & $\begin{array}{l}\text { Adaptive capacity } \\
\text { component. } \\
\text { High irrigation ratio implies } \\
\text { high adaptive capacity and } \\
\text { lower drought vulnerability. }\end{array}$ & Negative & $\begin{array}{c}\text { Web based land use statistics } \\
\text { information system } \\
\text { https://aps.dac.gov.in/LUS/Index.htm }\end{array}$ & & $\begin{array}{c}\text { Irrigation water } \\
\text { consumption, Irrigation } \\
\text { water withdrawal (RCP2.6- } \\
\text { SSP2 \& RCP6.0-SSP2) }\end{array}$ \\
\hline $\begin{array}{l}\text { Water bodies } \\
\text { fraction }\end{array}$ & $\begin{array}{c}\text { Water resources } \\
\text { (streams/rivers) and water } \\
\text { infrastructure } \\
\text { (dams/reservoirs) for } \\
\text { assessing the physical } \\
\text { vulnerability. }\end{array}$ & Negative & Bhuvan-Indian Geo Platform & & $\begin{array}{l}\text { Surface runoff, Total runoff, } \\
\text { Total water storage (RCP2.6 } \\
\text {-SSP2 \& RCP6.0-SSP2) }\end{array}$ \\
\hline Groundwater & $\begin{array}{l}\text { Adaptive capacity } \\
\text { component to cope with } \\
\text { drought. }\end{array}$ & Negative & $\begin{array}{l}\text { Dynamic Ground Water Resources of } \\
\text { India, Central Ground Water Board } \\
\text { Ministry of Water Resources, Report on } \\
\text { July 2011, (CGWB, 2014) }\end{array}$ & & $\begin{array}{l}\text { Groundwater runoff, Total } \\
\text { water storage (RCP2.6 - } \\
\text { SSP2 \& RCP6.0-SSP2) }\end{array}$ \\
\hline $\begin{array}{l}\text { Land Use } \\
\text { Land Cover } \\
\text { (LULC) }\end{array}$ & $\begin{array}{c}\text { Accounts for social } \\
\text { vulnerability to drought due } \\
\text { to exposure. }\end{array}$ & Positive & $\begin{array}{c}\text { The USGS Land Cover Institute (LCI) } \\
\text { (https://landcover.usgs.gov/global_clima } \\
\text { tology.php) }\end{array}$ & $\begin{array}{c}\text { NASA Earthdata from } \\
\text { ORNL DAAC (Chini et } \\
\text { al. 2014) } \\
\text { (https://doi.org/10.3334/O } \\
\text { RNLDAAC/1248) }\end{array}$ & $\begin{array}{c}\text { Fractional Land Use Land } \\
\text { Cover data (RCP2.6 \& } \\
\text { RCP6.0) }\end{array}$ \\
\hline $\begin{array}{c}\text { Digital } \\
\text { Elevation } \\
\text { Model (DEM) }\end{array}$ & $\begin{array}{l}\text { Spare time for water } \\
\text { retention bestows higher } \\
\text { adaptive capacity in flat } \\
\text { slope parts. Accounts for } \\
\text { physical vulnerability to } \\
\text { drought. }\end{array}$ & Positive & $\begin{array}{l}\text { SRTM } 90 \text { m Digital Elevation Database } \\
\text { v4.1 (http://www.cgiar- } \\
\text { csi.org/data/srtm-90m-digital-elevation- } \\
\text { database-v4-1\#download) }\end{array}$ & \multirow{2}{*}{\multicolumn{2}{|c|}{ Constant (same as observed) }} \\
\hline Soil Type & $\begin{array}{l}\text { Water holding capacity of } \\
\text { soil based on the textural } \\
\text { properties. } \\
\text { Accounts for social } \\
\text { vulnerability to drought due } \\
\text { to exposure. }\end{array}$ & Positive & $\begin{array}{l}\text { FAO Harmonized World Soil Database } \\
\text { (HWSD) (http://www.fao.org/soils- } \\
\text { portal/soil-survey/soil-maps-and- } \\
\text { databases/harmonized-world-soil- } \\
\text { database-v12/en/) }\end{array}$ & & \\
\hline
\end{tabular}




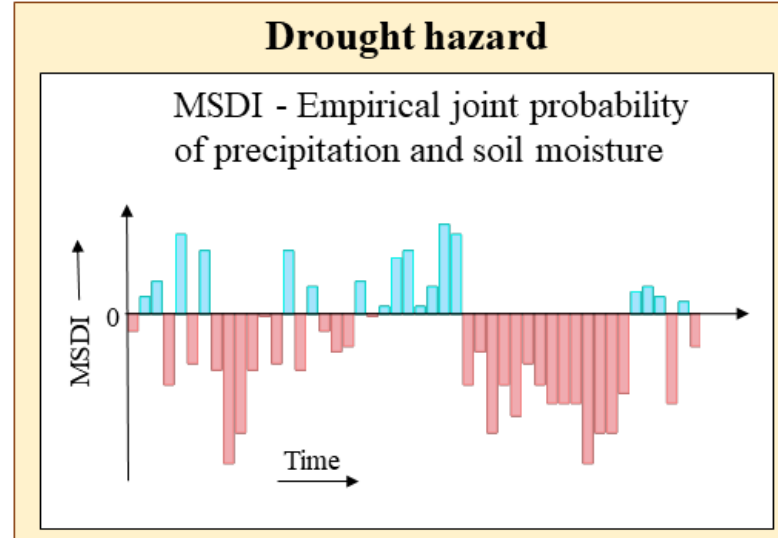

Weights and ratings based on cdf of MSDI
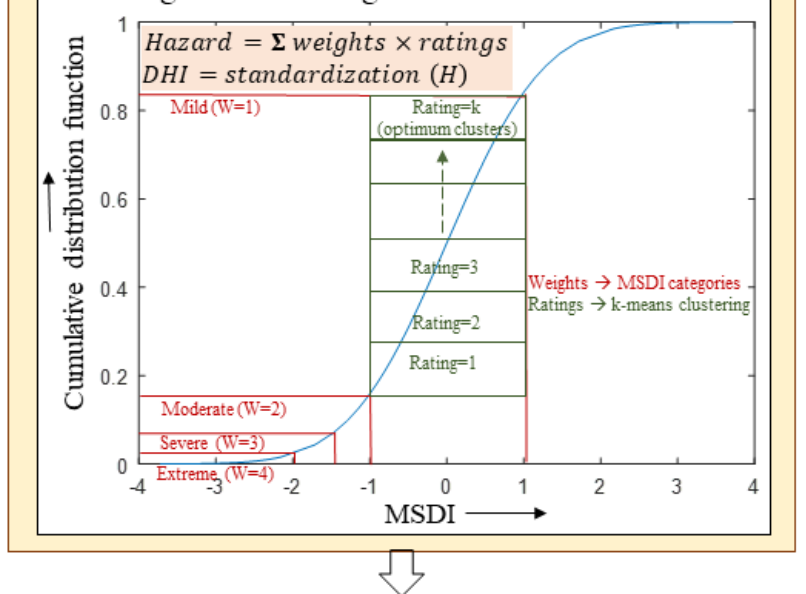

\section{Climate change + Socio-economic scenarios}

1) Mitigation + Middle-of-the-road (RCP2.6 + SSP2 )

2) Medium stabilization + Middle-of-the-road(RCP6.0 + SSP2 )

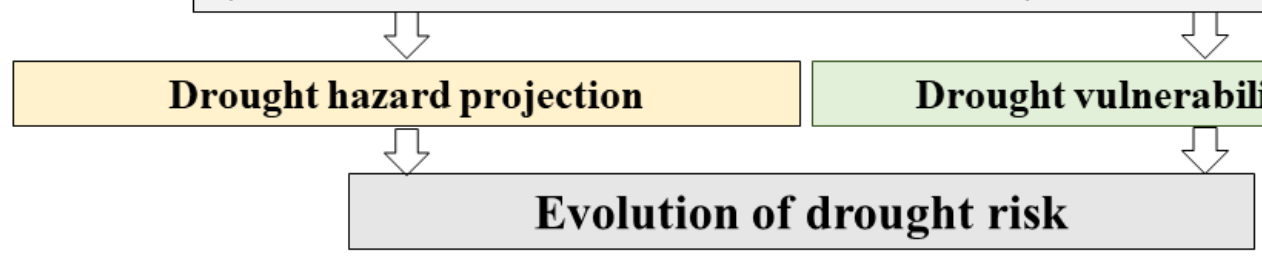

Figure 1. Framework to assess drought risk evolution. Monthly rainfall and monthly soil moisture is used to compute multivariate standardized drought index (MSDI). Weights and ratings system of MSDI is adopted to further compute drought hazard index (DHI). Multi-criteria decision making technique - TOPSIS is used to calculate drought vulnerability index (DVI) considering eight drought vulnerability indicators. The product of DHI and DVI is the drought risk index (DRI). Drought risk assessment is carried out for baseline period (1980-2015), near future (2021-2050) and far future (2061-2100) for various climate and socio-economic scenarios. 


\section{Results and discussion}

\subsection{Drought hazard}

\subsubsection{Projection of hydro-climatic variables}

The multi-model ensemble precipitation and soil moisture data from the four GCMs is used for drought hazard assessment. The country-wide accumulated data of these hydro-climatic variables is shown in Figure 2. The projected precipitation as well as soil moisture for the RCP6.0 scenario is high compared to the RCP2.6 scenario. Further, it is noted that the variability in both the variables increases with time. However, the variability in the hydro-climatic variables in the baseline period is high compared to the projected period.

\subsubsection{Projection of drought hazard}

The multi-model ensemble drought hazard for different RCP scenarios and time slices along with the baseline period are shown

in Figure 3. It is observed that the projected hazard over many regions is less compared to the baseline period. However, certain parts of north-western India and east coastal regions are under high drought hazard class. The hazard transition from the baseline to different scenarios is presented in Table 2. In general, a transition from higher hazard classes to lower hazard classes is observed under the projected scenarios, implying that more regions in the country are expected to come under low hazard category in the future. The future drought hazard assessment using the projected hydro-climatic variables revealed that more than 35\% area of the country is expected to be under the low hazard class, as compared to $8 \%$ in the baseline period (refer Table 2). It is also interesting that the area under high hazard class is greater in the far future as compared to the near future irrespective of the RCP scenarios. This is ascribed to the higher variability of the hydro-climatic variables in far future compared to the near future period that resulted in higher magnitude of drought events. Of all the future drought hazard scenarios considered, the RCP2.6-Far scenario revealed the largest area (2.8\%) under high and very high hazard classes. This accounts for a 7\% reduction in high and very high hazard classes compared to the baseline scenario. It is observed that NorthWestern India, parts of Jammu, Kashmir, Andhra Pradesh and Marathwada come under high hazard classes.

It is interesting to note that the probabilistic Budyko framework-based projected annual per capita water availability analysis (PCWA) for the Indian region by Singh \& Kumar (2019) show a decrease in PCWA in $2.0^{\circ} \mathrm{C}$ warmer world compared to 1.5 ${ }^{\circ} \mathrm{C}$ warmer world under CMIP5-based mitigation, medium stabilization and high-end (RCP8.5) climate change scenarios,

160 indicating high hazard in the far future. Similarly, higher drought hazard is observed in the far future compared to the near future by Gupta \& Jain (2018) \& Gupta et al. (2020) who performed SPEI-based drought hazard analysis using CMIP5 GCMs under high-end climate change. Further, frequency-based soil moisture droughts analysis by Aadhar \& Mishra (2020) using CMIP6-based SSP-RCP scenarios and Aadhar \& Mishra (2021) using Community earth system model large ensemble-based high-end climate change and SPEI-based drought frequency analysis by Zhai et al. (2020) using both CMIP5 and CMIP6 scenarios show an increased drought frequency in the future period over South Asia compared to the baseline period. This 
shows that far future period is more prone to drought hazard than the near future. On the other hand, few studies such as Koutroulis et al. (2019) \& Cook et al. (2020), who used CMIP5 and CMIP6 simulations respectively show that drought exposure/frequency over the Indian region decrease with time. Such contradicting observations are possibly due to selection of low-skill GCMs (Aadhar and Mishra, 2020).

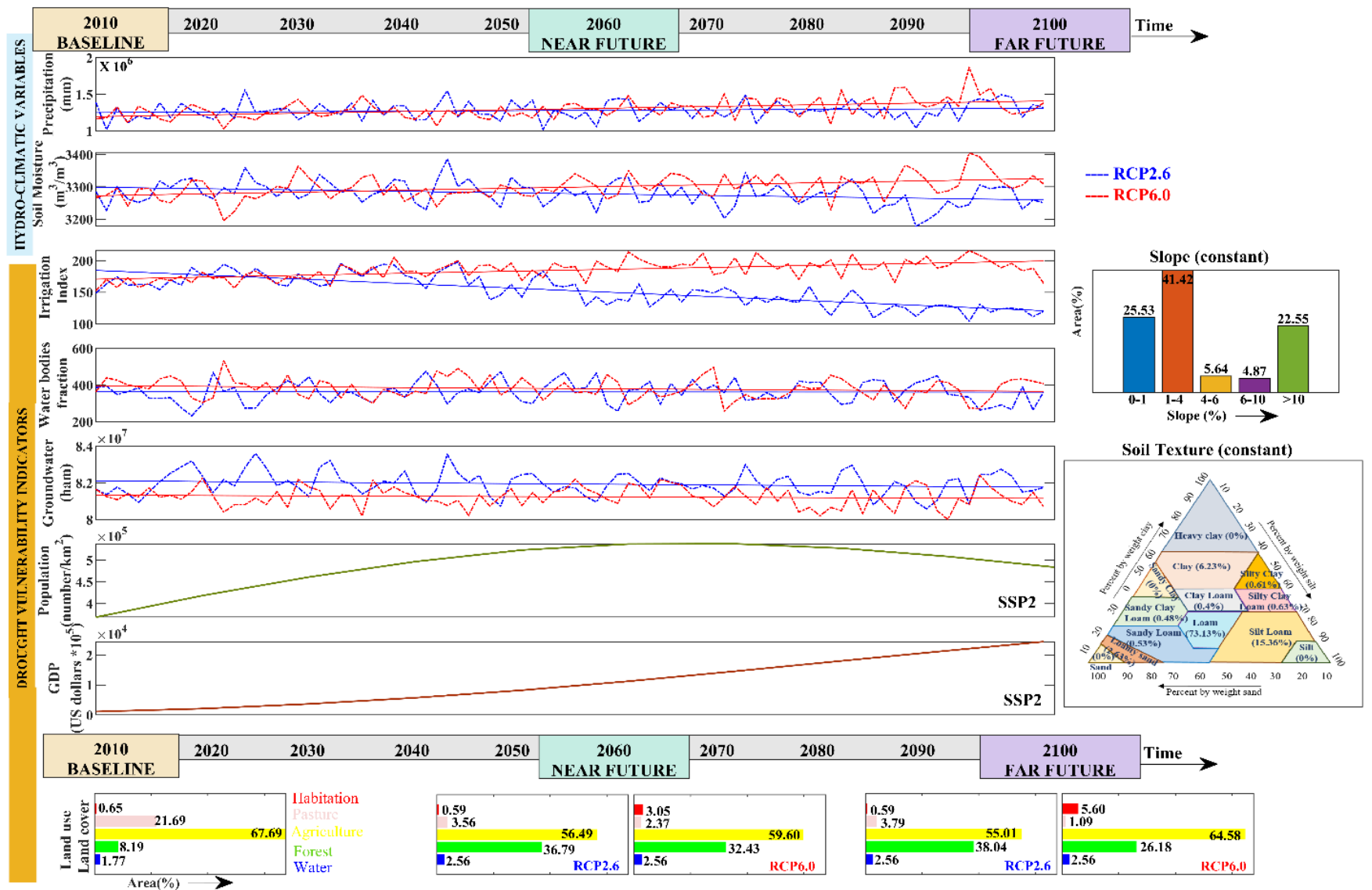

Figure 2. Datasets used for drought risk assessment. Projected hydro-climatic variables such as monthly precipitation and monthly soil moisture are used for drought hazard assessment. Projected drought vulnerability indicators such as irrigation index, water body fraction, groundwater availability, population, GDP and land use land cover, along with static drought vulnerability indicators such as slope and soil texture are used for drought vulnerability assessment. Datasets for projected period are divided into near future (2021-2060) and far future (2061-2100) to check the evolution of drought risk. 
https://doi.org/10.5194/nhess-2022-18

Preprint. Discussion started: 24 February 2022

(c) Author(s) 2022. CC BY 4.0 License.
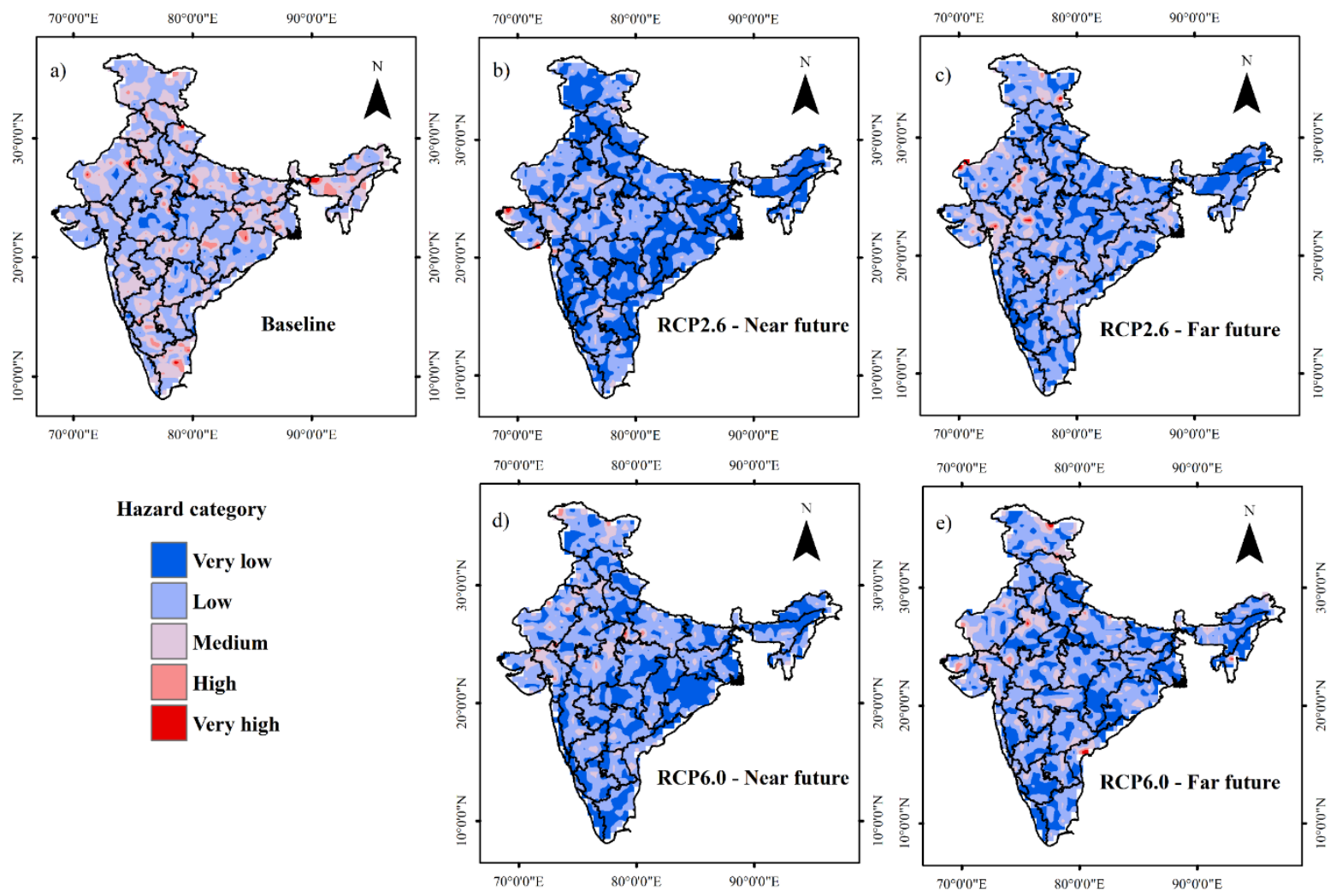

Figure 3. Multi-model ensemble drought hazard maps for the scenarios a) baseline, b) RCP2.6 Near future, c) RCP2.6 Far future, d) RCP6.0 Near future, e) RCP6.0 Far future.

180 Table 2. Transition of drought hazard from baseline period to projected period. The value in each cell represents the change in \% area of the country from one hazard class to another.
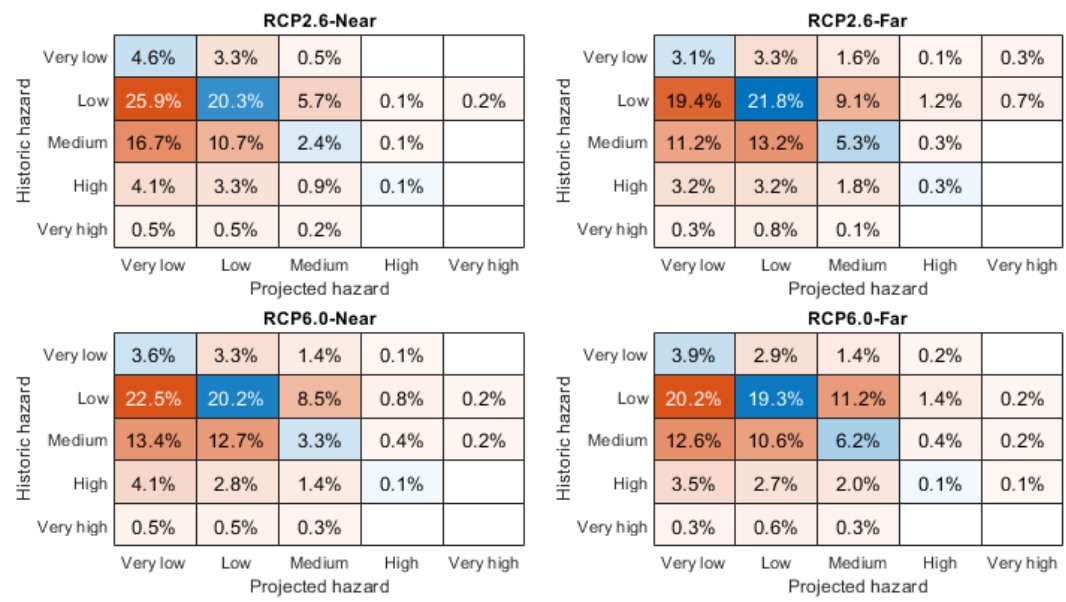


\subsection{Drought vulnerability}

\subsubsection{Projection of drought vulnerability indicators}

The varying drought vulnerability indicators for the drought vulnerability assessment is shown in Figure 2. It is observed that GDP increases with time continuously, whereas population reaches its peak during the end of near future (2060) and decreases gradually by the end of the century. The representative indicators obtained through human influences, varying land use and water abstractions according to the RCP2.6-SSP2 and RCP6.0-SSP2 conditions are used to derive the drought vulnerability indicators such as irrigation index, waterbody fraction and groundwater availability for the projected period. It is observed that the irrigation index rises in the case of RCP6.0-SSP2 and declines in the case of RCP2.6-SSP2 owing to the changes in irrigation water consumption and irrigation water withdrawal. On the other hand, groundwater availability and waterbody fraction under both RCP2.6-SSP2 and RCP6.0-SSP2 is found to decrease. Highest differences in land use land cover changes is observed in RCP6.0 condition compared to RCP2.6. It is also seen that \% area under habitation increases continuously with time in the case of RCP6.0. Slope and soil texture data is assumed to be constant (Figure S3).

\subsubsection{Projection of drought vulnerability}

The multi-model ensemble drought vulnerability projections for different scenarios is presented in Figure 4. It is observed that many regions of the country is expected to be more vulnerable to drought compared to the baseline period. In general, parts of North-Western, eastern India and southern coast are observed to be under high vulnerability class in the future scenarios. The vulnerability transition from the baseline to different scenarios is presented in Table 3. It can be observed that the drought vulnerability under RCP6.0-SSP2 scenario is worst compared to the RCP2.6-SSP2 scenario, since high transition from lower vulnerability classes to higher vulnerability classes is observed in the former case. As high as $42.9 \%$ area transits from lower vulnerability classes to higher vulnerability classes under RCP6.0-SSP2 Near future. Also, a 33\% increase in the area under high and very high vulnerability classes is observed in this worst-case scenario, with North-Western India, Western Coast and parts of Chattisgarh, Odisha and Jharkhand under very high vulnerability class.

In the global freshwater vulnerability analysis conducted by Koutroulis et al. (2019), although they show that sensitivity component of the overall freshwater vulnerability is increasing with time, an increasing adaptive capacity and decreasing exposure is reducing India's vulnerability to drought. However, our study shows an increasing vulnerability to drought, considering sensitivity, adaptive capacity as well as exposure factors. Such contradicting observations in drought vulnerability is possibly due the choice of low-skill GCMs.

Next, we aggregate hazard and vulnerability information on meteorological sub-division-wise scale to identify the subdivisions under critical drought condition due to the interplay of hazard and vulnerability. Scatter of drought hazard and drought vulnerability for 30 sub-divisions is shown in Figure S4. It is seen that West Rajasthan, Odisha, Haryana and West Uttar 
https://doi.org/10.5194/nhess-2022-18

Preprint. Discussion started: 24 February 2022

(c) Author(s) 2022. CC BY 4.0 License.
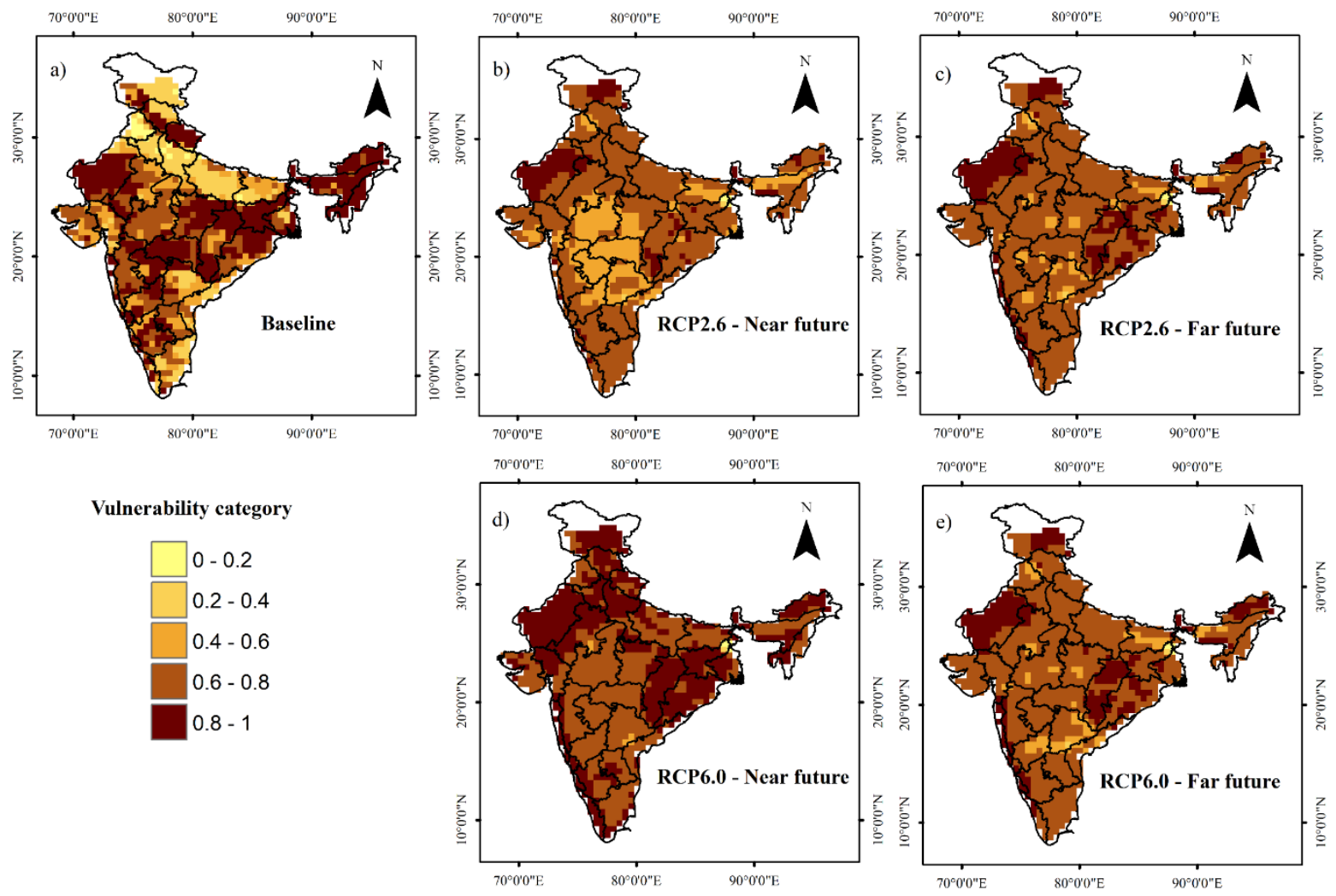

215 Figure 4. Multi-model ensemble drought vulnerability maps for the scenarios a) baseline, b) RCP2.6-SSP2 Near future, c) RCP2.6SSP2 Far future, d) RCP6.0-SSP2 Near future, e) RCP6.0-SSP2 Far future.

Table 3. Transition of drought vulnerability from baseline period to projected period. The value in each cell represents the change in $\%$ area of the country from one vulnerability class to another.
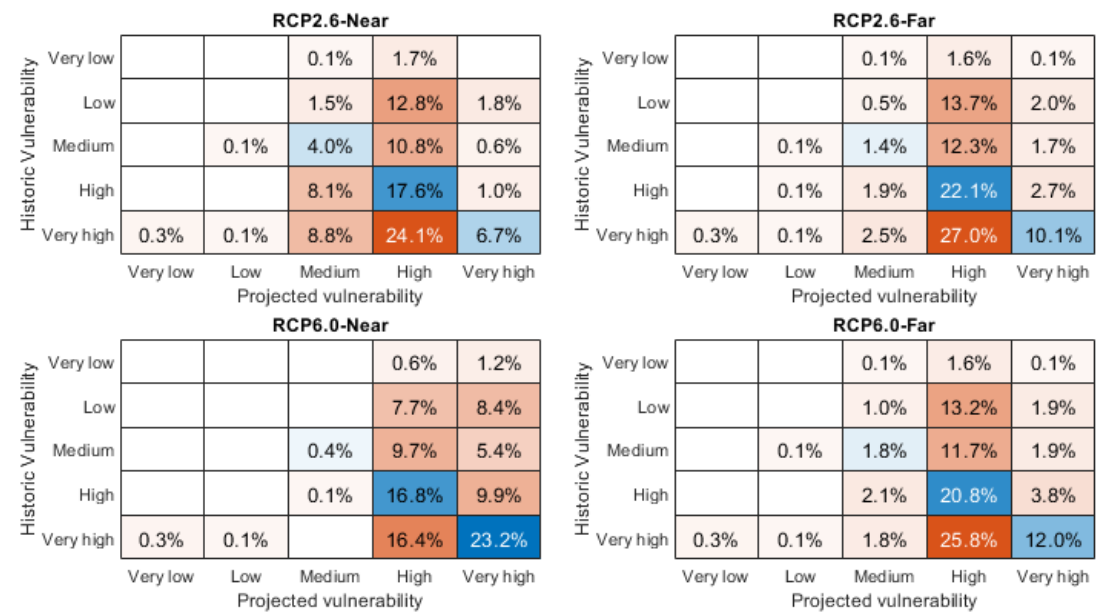
Pradesh sub-divisions are expected to be under high risk to drought compared to the other sub-divisions in all the scenarios. Further, the number of sub-divisions falling under critical drought risk (DHI > 0.25, DVI > 0.75) is high in the case of RCP6.0SSP2 scenario, with 22 meteorological subdivisions under high vulnerability (DVI > 0.75), particularly in RCP6.0-SSP2-Near future scenario.

\subsection{Drought risk}

\subsubsection{Projection of drought risk}

The multi-model ensemble drought hazard and vulnerability projections under different scenarios are combined according to Eq 1 to obtain drought risk projections (Figure 5). It is noted that parts of the North-Western India is expected to be more prone to drought risk compared to the baseline period. On the other hand, Central Indian regions are expected to switch to lower risk classes. The risk transition from the baseline to different scenarios is presented in Table 4. Highest transition (30\% area) from lower risk to higher risk classes is observed in RCP6.0-SSP2-Far future scenario. Also, overall drought risk reduces by $0.8 \%$ in this scenario compared to the baseline. It is interesting to note that the RCP6.0-SSP2 Far future scenario is not the worstcase scenario in drought vulnerability projection, yet it turned out to be worst-case scenario in drought risk projection due to high drought hazard projection, revealing the importance of comprehensive drought risk assessment. Further, projected bivariate choropleth maps for unique combinations of DHI and DVI is presented Figure 6. It is seen that most of the regions are constituted by low hazard and high vulnerability indicating high impact of societal developments rather than climateinvoked changes. Hence it is important to take the drought mitigation plans based on the socio-economic conditions instead of just considering hydro-climatic conditions of the interested region. Consolidated results showing the $\%$ area of different classes of drought hazard, vulnerability and risk under various climate and socio-economic scenarios are given in Figure 7.

\subsubsection{Potential applications}

The drought hazard, vulnerability and risk projection maps that are developed in this study can be used by administrators, policy makers and drought managers to prioritize areas for drought mitigation. The change in drought risk at different projected periods can modulate adaptation and mitigation strategies and can be included in decision support system for drought management. Since drought risk is found to be mainly driven by societal factors, action plans should be directed to improve socio-economic conditions. Groundwater conservation, conjunctive use of surface and groundwater, farmer participation in crop insurance, water saving farm practices and technologies are some important measures that can be adopted for raising the socio-economic standards. Further, the framework of our study is applicable for state-wise drought risk assessment with reliable hydro-climatic and socio-economic indicators. Such an assessment is useful to suggest region-specific measures for watershed management, irrigation and agricultural practices and reorganizing water demand and supply management. 
https://doi.org/10.5194/nhess-2022-18

Preprint. Discussion started: 24 February 2022

(c) Author(s) 2022. CC BY 4.0 License.
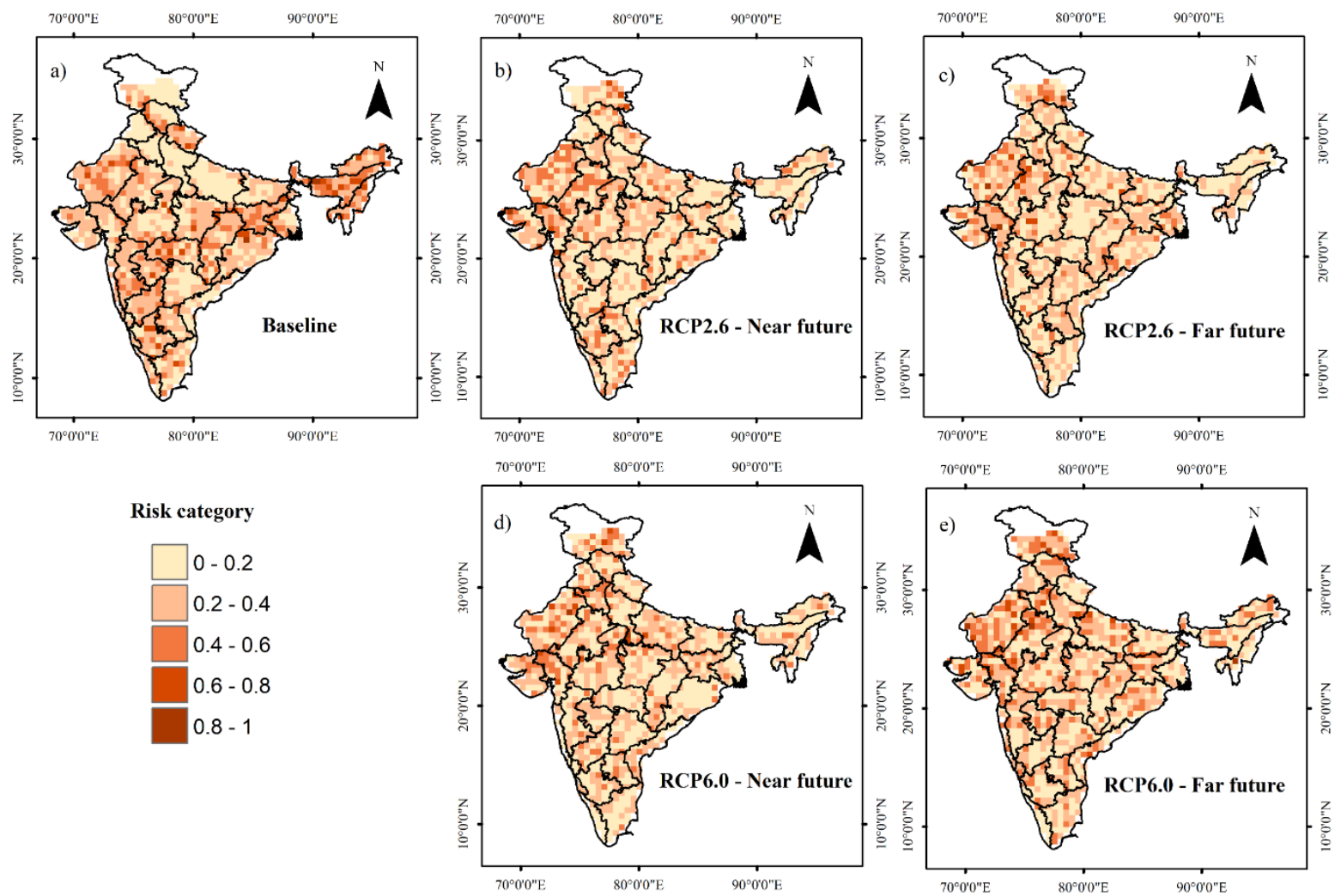

Figure 5. Multi-model ensemble drought risk maps for the scenarios a) baseline, b) RCP2.6-SSP2 Near future, c) RCP2.6-SSP2 Far future, d) RCP6.0-SSP2 Near future, e) RCP6.0-SSP2 Far future.

255 Table 4. Transition of drought risk from baseline period to projected period. The value in each cell represents the change in \% area of the country from one risk class to another.

\begin{tabular}{|c|c|c|c|c|c|}
\hline \multirow[b]{2}{*}{ Very low } & \multicolumn{5}{|c|}{ RCP2.6-Near } \\
\hline & $17.5 \%$ & $13.6 \%$ & $3.3 \%$ & $0.4 \%$ & $0.1 \%$ \\
\hline \multirow{4}{*}{$\begin{array}{r}\text { Low } \\
\text { Medium } \\
\text { High } \\
\text { Very high }\end{array}$} & $23.6 \%$ & $16.4 \%$ & $6.3 \%$ & $0.1 \%$ & $0.2 \%$ \\
\hline & $8.0 \%$ & $5.3 \%$ & $1.8 \%$ & & \\
\hline & $1.6 \%$ & $1.2 \%$ & $0.5 \%$ & & \\
\hline & & $0.3 \%$ & & & \\
\hline & Very low & Low & Projected risk & ${ }^{\text {High }}$ & Very high \\
\hline Very low & $16.4 \%$ & $13.4 \%$ & $4.4 \%$ & $0.6 \%$ & $0.1 \%$ \\
\hline \multirow{5}{*}{ 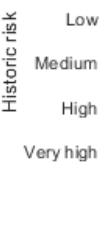 } & $22.9 \%$ & $18.5 \%$ & $4.7 \%$ & $0.3 \%$ & $0.1 \%$ \\
\hline & $7.2 \%$ & $6.4 \%$ & $1.2 \%$ & $0.2 \%$ & $0.1 \%$ \\
\hline & $1.8 \%$ & $1.1 \%$ & $0.4 \%$ & & \\
\hline & $0.2 \%$ & $0.1 \%$ & & & \\
\hline & Very low & \multicolumn{4}{|c|}{ Projected risk } \\
\hline
\end{tabular}

\begin{tabular}{|c|c|c|c|c|c|}
\hline \multirow[b]{2}{*}{ Very low } & \multicolumn{5}{|c|}{ RCP2.6-Far } \\
\hline & $16.2 \%$ & $14.5 \%$ & $3.5 \%$ & $0.4 \%$ & $0.2 \%$ \\
\hline \multirow{3}{*}{$\begin{array}{r}\text { Low } \\
\text { Medium } \\
\text { High }\end{array}$} & $24.1 \%$ & $18.2 \%$ & $3.6 \%$ & $0.4 \%$ & $0.2 \%$ \\
\hline & $7.8 \%$ & $5.5 \%$ & $1.6 \%$ & $0.1 \%$ & $0.1 \%$ \\
\hline & $1.8 \%$ & $1.1 \%$ & $0.4 \%$ & & \\
\hline \multirow[t]{2}{*}{ Very high } & & $0.3 \%$ & & & \\
\hline & Very low & Low & $\begin{array}{r}\text { Medium } \\
\text { ojected } \\
\text { CP6.0-1 }\end{array}$ & High & Very high \\
\hline Very low & $14.0 \%$ & $13.1 \%$ & $6.7 \%$ & $0.9 \%$ & $0.1 \%$ \\
\hline \multirow{3}{*}{ 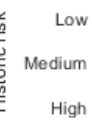 } & $20.9 \%$ & $16.9 \%$ & $7.4 \%$ & $1.1 \%$ & $0.2 \%$ \\
\hline & $6.6 \%$ & $5.3 \%$ & $2.8 \%$ & $0.3 \%$ & $0.1 \%$ \\
\hline & $1.6 \%$ & $1.4 \%$ & $0.3 \%$ & & \\
\hline \multirow[t]{2}{*}{ Very high } & $0.1 \%$ & $0.1 \%$ & $0.1 \%$ & & \\
\hline & Very low & Low & Projected risk & High & Very high \\
\hline
\end{tabular}


https://doi.org/10.5194/nhess-2022-18

Preprint. Discussion started: 24 February 2022

(c) Author(s) 2022. CC BY 4.0 License.
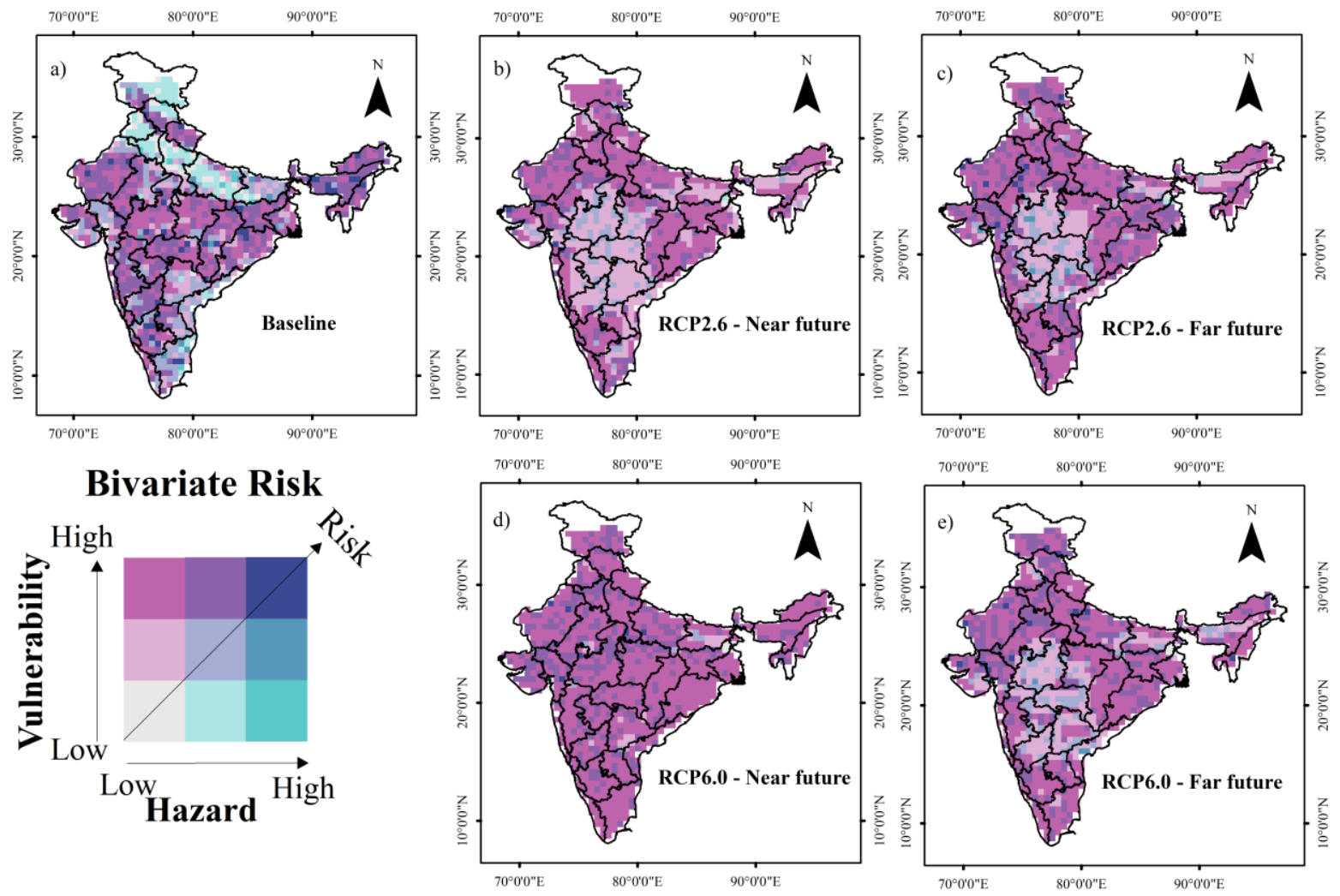

Figure 6. Bivariate choropleth drought risk maps showing hazard-driven and vulnerability-driven drought risk for the scenarios a) baseline, b) RCP2.6-SSP2 Near future, c) RCP2.6-SSP2 Far future, d) RCP6.0-SSP2 Near future, e) RCP6.0-SSP2 Far future.

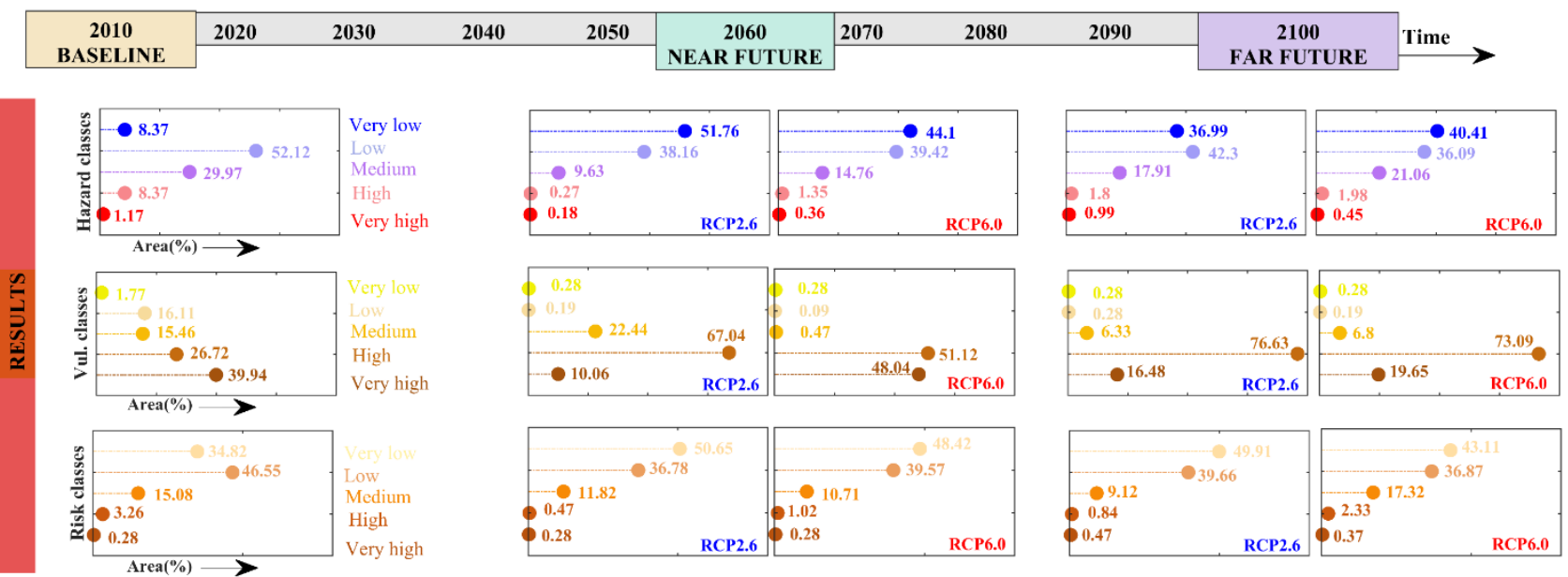

Figure 7. Summary of drought risk evolution. \% area of different classes of drought hazard, vulnerability and risk under various climate and socio-economic scenarios. 


\section{Concluding remarks}

265 This study presents future projections of drought risk over India under changing climate and socio-economic conditions. This is achieved combining the drought hazard and drought vulnerability projections. Drought hazard assessment is carried out using a multivariate drought index known as MSDI, an indicator of agro-meteorological drought. Drought vulnerability is assessed using a robust MCDM technique called TOPSIS, considering changes in relevant socio-economic indicators. Consideration of projections of multiple drought vulnerability indicators in this study is a significant improvement over existing studies on drought risk assessment in India under climate change. Further, we present for the first time, future projected bivariate choropleth plots to identify the drivers of overall drought risk across the country. The multi-model ensemble drought hazard and drought vulnerability are computed for the two RCP-SSP scenarios- RCP2.6-SSP2 and RCP6.0-SSP2 for the near and far future timelines. The current study is limited by simulations from a single global vegetation model rather than multiple impact models including hydrologic or land surface simulations. Important conclusions of the study are outlined below.

1. The MSDI-based drought hazard assessment reveals that more than $35 \%$ area in India is projected to be under low hazard class as opposed to $8 \%$ in the baseline period, possibly due to rising precipitation in the region as projected by climate models. RCP2.6-Far scenario shows $2.8 \%$ area of the country under high and very high hazard classes, accounting for $7 \%$ reduction in those two drought hazard categories. In general, the spatial extent of high and very high hazard classes is greater in far future as compared to the near future.

2. Drought vulnerability is projected to increase for all scenarios, with $77 \%$ area under high or very high vulnerability class as compared to $66 \%$ in the baseline period. A rise in $33 \%$ of area under high or very high vulnerability class is observed in RCP6.0-SSP2-Near future scenario.

3. Among the two RCP-SSP scenarios considered, RCP6.0-SSP2 scenario exhibits worst cases due to high transition from lower to higher vulnerability classes as compared to RCP2.0-SSP2 scenario.

4. Integration of drought hazard and vulnerability projections shows an overall decrease in drought risk projections, resulting primarily from reduction in drought hazard. However, a transition from lower to higher risk classes ranging upto $30 \%$ is observed in RCP6.0-SSP2 Far scenario.

5. Meteorological sub-divisions such as West Rajasthan, Odisha, Haryana and West Uttar Pradesh are expected to be under high risk in the projected period under all the scenarios.

6. Bivariate choropleth analysis show that future drought risk is significantly driven by increased vulnerability resulting from societal developments rather than climate-induced changes in hazard. Therefore, future efforts on building drought resilience in the country must include strengthening socio-economic conditions. 


\section{Author contribution}

V. Sahana and Arpita Mondal designed the study. V. Sahana conducted the analysis, generated the results and wrote the first draft. Both the authors contributed in writing and revising the manuscript.

\section{Competing interests}

The authors declare that they have no known competing interests or personal relationships that could have appeared to influence the work reported in this paper.

\section{Acknowledgements}

300 The authors are thankful to the IMD, Pune, NASA Modern-Era Retrospective Analysis for Research and Application - Land (https://disc.sci.gsfc.nasa.gov/), NASA Global Inventory Modelling and Mapping Studies (https://nex.nasa.gov/nex/projects/1349/) for providing essential data for drought hazard assessment, all the agencies mentioned in Table 1 for providing drought vulnerability indicator datasets and the Postdam-Institute for Climate Impact Research for providing ISIMIP data (https://esg.pik-potsdam.de/search/isimip/) for drought risk projection study. The authors

305 appreciate the financial support received from the Science and Engineering Research Board, Department of Science and Technology, Government of India, through the project ECR/2017/000566 and SPLICE-Climate Change Programme, Department of Science and Technology, Government of India, through the project DST/CCP/CoE/140/2018. The authors also thank Mr. Roshan Jha for his comments on the first draft.

\section{References}

310 Aadhar, S. and Mishra, V.: On the Projected Decline in Droughts Over South Asia in CMIP6 Multimodel Ensemble, J. Geophys. Res. Atmos., 125(20), 1-18, doi:10.1029/2020JD033587, 2020.

Aadhar, S. and Mishra, V.: On the occurrence of the worst drought in South Asia in the observed and future climate, Environ. Res. Lett., 16(2), 024050, doi:10.1088/1748-9326/abd6a6, 2021.

AghaKouchak, A.: A multivariate approach for persistence-based drought prediction: Application to the 2010-2011 East Africa 315 drought, J. Hydrol., 526, 127-135, doi:10.1016/j.jhydrol.2014.09.063, 2015.

Ahmadalipour, A., Moradkhani, H., Castelletti, A. and Magliocca, N.: Future drought risk in Africa: Integrating vulnerability, climate change, and population growth, Sci. Total Environ., 662, 672-686, doi:10.1016/j.scitotenv.2019.01.278, 2019.

Carrão, H., Naumann, G. and Barbosa, P.: Mapping global patterns of drought risk: An empirical framework based on subnational estimates of hazard, exposure and vulnerability, Glob. Environ. Chang., 39, 108-124, doi:10.1016/j.gloenvcha.2016.04.012, 2016. 
Chen, L., Wang, G., Miao, L., Raj, G. K., Li, S., Amankwah, S. O. Y., Huang, J., Lu, J. and Zhan, M.: Future drought in CMIP6 projections and the socioeconomic impacts in China Liqin Chen, Int. J. Climatol., doi:10.1002/joc.7064, 2021.

Chini, L. P., Hurtt, G. C., and Frolking, S.: Harmonized global land use for years 1500-2100, V1. ORNL DAAC, 2014.

Cook, B. I., Mankin, J. S., Marvel, K., Williams, A. P., Smerdon, J. E. and Anchukaitis, K. J.: Twenty-First Century Drought

Projections in the CMIP6 Forcing Scenarios, Earth's Futur., 8(6), 1-20, doi:10.1029/2019EF001461, 2020.

Farahmand, A. and AghaKouchak, A.: A generalized framework for deriving nonparametric standardized drought indicators, Adv. Water Resour., 76, 140-145, doi:10.1016/j.advwatres.2014.11.012, 2015.

Ghosh, T., Powell, R. L., Elvidge, C. D., Baugh, K. E., Sutton, P. C. and Anderson, S.: Shedding Light on the Global Distribution of Economic Activity, Open Geogr. J., 148-161, 2010.

330 Grillakis, M. G.: Increase in severe and extreme soil moisture droughts for Europe under climate change, Sci. Total Environ., 660, 1245-1255, doi:10.1016/j.scitotenv.2019.01.001, 2019.

Gu, X., Li, J., Chen, Y. D., Kong, D. and Liu, J.: Consistency and Discrepancy of Global Surface Soil Moisture Changes From Multiple Model-Based Data Sets Against Satellite Observations, J. Geophys. Res. Atmos., 124(3), 1474-1495, doi:10.1029/2018JD029304, 2019.

335 Gupta, V. and Jain, M. K.: Investigation of multi-model spatiotemporal mesoscale drought projections over India under climate change scenario, J. Hydrol., 567, 489-509, 2018.

Gupta, V., Jain, M. K. and Singh, V. P.: Multivariate Modeling of Projected Drought Frequency and Hazard over India, J. Hydrol. Eng., 25(4), 1-19, doi:10.1061/(ASCE)HE.1943-5584.0001893, 2020.

Jia, B., Cai, X., Zhao, F., Liu, J., Chen, S., Luo, X., Xie, Z. and Xu, J.: Potential future changes of terrestrial water storage 340 based on climate projections by ensemble model simulations, Adv. Water Resour., 142(November 2019), doi:10.1016/j.advwatres.2020.103635, 2020.

Kim, H. J., Cho, K., Kim, Y., Park, H., Lee, J. W., Kim, S. J. and Chae, Y.: Spatial Assessment of Water-Use Vulnerability under Future Climate and Socioeconomic Scenarios within a River Basin, J. Water Resour. Plan. Manag., 146(7), 05020011, doi:10.1061/(asce)wr.1943-5452.0001235, 2020.

345 Koutroulis, A. G., Papadimitriou, L. V., Grillakis, M. G., Tsanis, I. K., Wyser, K. and Betts, R. A.: Freshwater vulnerability under high end climate change. A pan-European assessment, Sci. Total Environ., 613-614, 271-286, doi:10.1016/j.scitotenv.2017.09.074, 2018.

Koutroulis, A. G., Papadimitriou, L. V., Grillakis, M. G., Tsanis, I. K., Warren, R. and Betts, R. A.: Global water availability under high-end climate change: A vulnerability based assessment, Glob. Planet. Change, 175, 52-63, doi:10.1016/j.gloplacha.2019.01.013, 2019a.

Koutroulis, A. G., Papadimitriou, L. V., Grillakis, M. G., Tsanis, I. K., Warren, R. and Betts, R. A.: Global water availability under high-end climate change: A vulnerability based assessment, Glob. Planet. Change, 175(August 2018), 52-63, doi:10.1016/j.gloplacha.2019.01.013, 2019b. 
Mishra, A. K. and Singh, V. P.: A review of drought concepts, J. Hydrol., 391, 202-216, doi:10.1016/j.jhydrol.2010.07.012, 2010

Mishra, A. K. and Singh, V. P.: Drought modeling - A review, J. Hydrol., 403, 157-175, doi:10.1016/j.jhydrol.2011.03.049, 2011.

Mohanty, M. P., H, V., Yadav, V., Ghosh, S., Rao, G. S. and Karmakar, S.: A new bivariate risk classifier for flood management considering hazard and socio-economic dimensions, J. Environ. Manage., 255, 109733, doi:10.1016/j.jenvman.2019.109733, 2020.

Naumann, G., Barbosa, P., Garrote, L., Iglesias, A. and Vogt, J.: Exploring drought vulnerability in Africa: an indicator based analysis to be used in early warning systems, Hydrol. Earth Syst. Sci., 18(5), 1591-1604, 2014.

O’Neill, B. C., Kriegler, E., Ebi, K. L., Kemp-Benedict, E., Riahi, K., Rothman, D. S., van Ruijven, B. J., van Vuuren, D. P., Birkmann, J., Kok, K., Levy, M. and Solecki, W.: The roads ahead: Narratives for shared socioeconomic pathways describing world futures in the 21st century, Glob. Environ. Chang., 42, 169-180, doi:10.1016/j.gloenvcha.2015.01.004, 2017.

Pai, D. S., Sridhar, L., Rajeevan, M., Sreejith, O. P., Satbhai, N. S. and Mukhopadhyay, B.: Development of a new high spatial resolution $\left(0.25^{\circ} \times 0.25^{\circ}\right)$ long period $(1901-2010)$ daily gridded rainfall data set over India and its comparison with existing data sets over the region, Mausam, 65(1), 1-18, 2014.

Park, S. Y., Sur, C., Kim, J. S., Choi, S. J., Lee, J. H. and Kim, T. W.: Projected drought risk assessment from water balance perspectives in a changing climate, Int. J. Climatol., 41(4), 2765-2777, doi:10.1002/joc.6988, 2021.

Sahana, V., Sreekumar, P., Mondal, A. and Rajsekhar, D.: On the rarity of the 2015 drought in India: A country-wide drought atlas using the multivariate standardized drought index and copula-based severity-duration-frequency curves, J. Hydrol. Reg. Stud., 31, 100727, doi:10.1016/j.ejrh.2020.100727, 2020.

Sahana, V., Mondal, A. and Sreekumar, P.: Drought vulnerability and risk assessment in India: Sensitivity analysis and comparison of aggregation techniques, J. Environ. Manage., 299, 113689, doi:10.1016/j.jenvman.2021.113689, 2021.

Singh, R. and Kumar, R.: Climate versus demographic controls on water availability across India at $1.5^{\circ} \mathrm{C}, 2.0^{\circ} \mathrm{C}$ and $3.0^{\circ} \mathrm{C}$ global warming levels, Glob. Planet. Change, 177, 1-9, doi:10.1016/j.gloplacha.2019.03.006, 2019.

Sitch, S., Smith, B., Prentice, I. C., Arneth, A., Bondeau, A., Cramer, W., Kaplan, J. O., Levis, S., Lucht, W., Sykes, M. T., Thonicke, K. and Venevsky, S.: Evaluation of ecosystem dynamics, plant geography and terrestrial carbon cycling in the LPJ dynamic global vegetation model, Glob. Chang. Biol., 9(2), 161-185, doi:10.1046/j.1365-2486.2003.00569.x, 2003.

Vuuren, V., P, D., Edmonds, J., Kainuma, M., Riahi, K., Thomson, A., Hibbard, K., Hurtt, G. C., Kram, T., Krey, V., Lamarque, J.-F. and Others: The representative concentration pathways: an overview, Clim. Change, 109(1), 5-31, 2011.

Warszawski, L., Frieler, K., Huber, V., Piontek, F., Serdeczny, O. and Schewe, J.: The inter-sectoral impact model intercomparison project (ISI-MIP): Project framework, Proc. Natl. Acad. Sci. U. S. A., 111(9), 3228-3232, doi:10.1073/pnas.1312330110, 2014.

Zhai, J., Mondal, S. K., Fischer, T., Wang, Y., Su, B., Huang, J., Tao, H., Wang, G., Ullah, W. and Uddin, M. J.: Future drought 
https://doi.org/10.5194/nhess-2022-18

Preprint. Discussion started: 24 February 2022

(C) Author(s) 2022. CC BY 4.0 License.

(c) (i)

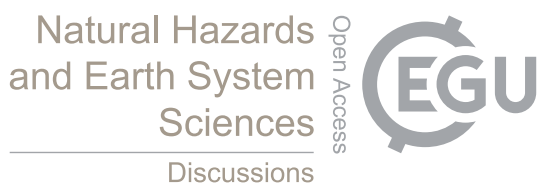

characteristics through a multi-model ensemble from CMIP6 over South Asia, Atmos. Res., 246, 105111, doi:10.1016/j.atmosres.2020.105111, 2020. 